\title{
PENGARUH MOTIVASI, KOMPENSASI, DAN \\ KEPUASAN KERJA TERHADAP KINERJA PEGAWAI \\ DENGAN KEPUASAN KERJA SEBAGAI VARIABEL INTERVENING
}

\author{
Sukidi ${ }^{1}$ dan Farid Wajdi ${ }^{2}$ \\ ${ }^{1)}$ Magister Manajemen Universitas Muhammadiyah Surakarta \\ ${ }^{2)}$ Fakultas Ekonomi dan Bisnis Universitas Muhammadiyah Surakarta, \\ Jl. A. Yani Pabelan Kartasura Surakarta 57102 \\ email: sukidi1569@gmail.com
}

\begin{abstract}
Abstrak
Penelitian ini bertujuan untuk menganalisis pengaruh motivasi dan kompensasi terhadap kepuasan kerja; pengaruh motivasi dan kompensasi terhadap kinerja pegawai; dan pengaruh kepuasan kerja terhadap kinerja pegawai di Dinas Pertanian, Perkebunan, dan Kehutanan Kabupaten Boyolali. Penelitian ini termasuk jenis penelitian kuantitatif. Sampel dalam penelitian berjumlah 60 orang yang diambil menggunakan teknik sampling jenuh. Pengumpulan data menggunakan metode angket. Penelitian ini menggunakan analisis jalur. Hasil penelitian ini menunjukkan motivasi dan kompensasi berpengaruh positif dan signifikan terhadap kepuasan kerja dan kinerja pegawai. Kepuasan kerja juga berpengaruh positif dan signifikan terhadap kinerja pegawai. Secara simultan motivasi dan kompensasi berpengaruh terhadap kepuasan kerja dan variabel motivasi, kompensasi, dan kepuasan kerja berpengaruh terhadap kinerja pegawai. Hasil analisis menunjukkan bahwa jalur langsung kepuasan kerja berpengaruh paling kuat terhadap kinerja pegawai yang ditunjukkan dengan memiliki koefisien regresi pengaruh paling tinggi (dominan) sebesar 0,404 .
\end{abstract}

Kata Kunci: Kepuasan kerja, motivasi, kompensasi, kinerja pegawai.

\section{Abstract}

This study aims to analyze how motivation and compensation effect on job satisfaction; motivation and compensation effect on employee performance; and job satisfaction effect on employees performance at the Department of Agriculture, Plantation, and Forestry of Boyolali Regency. This research type is quantitative research. The sample are 60 employees of the Department of Agriculture, Plantation, and Forestry of Boyolali Regency using saturation sampling technique. Methods of data collection using the questionnaire. This research using path analysis. The results showed that motivation and compensation have positive and significant impact on job satisfaction and employee performance. Job satisfaction have positive and significant effect on employee performance. The simultan of motivation and compensation effect on job satisfaction and variables of motivation, compensation, and job satisfaction effect on employee performance. The results showed that the direct path of job satisfaction has the most powerful effect on employee performance demonstrated by having the highest impact regression coefficient (dominant) amounted to 0,404.

Keywords: Job satisfication, motivation, compensation, employee performance. 


\section{Pendahuluan}

Dinas Pertanian, Perkebunan, dan Kehutanan Kabupaten Boyolali adalah lembaga penggerak perekonomian rakyat yang profesional di Kabupaten Boyolali yang mempunyai tugas pokok mewujudkan pertanian yang tangguh, maju, dan berkelanjutan. Tugas tersebut tertuang di dalam visi dan misi Dinas Pertanian, Perkebunan, dan Kehutanan Kabupaten Boyolali. Dengan visi dan misi tersebut, selayaknya seluruh pegawai Dispertanbunhut Kabupaten Boyolali memiliki kinerja yang baik sesuai dengan penjabaran yang ada. Akan tetapi, pada realitanya belum seluruh pegawai Dispertanbunhut Kabupaten Boyolali memiliki kinerja yang sesuai harapan. Fenomena yang terjadi terkait dengan kinerja Dispertanbunhut Kabupaten Boyolali adalah mangkirnya pegawai saat jam kantor atau usai hari libur nasional. Hal ini mengindikasikan bahwa kinerja di kalangan PNS belum tumbuh dan menjadi kesadaran kolektif.

Walaupun demikian, rendahnya kinerja pegawai tersebut merupakan anggapan atau persepsi beberapa atau sebagian kecil masyarakat yang menilai pelayanan yang diberikan kurang maksimal, sebab masih ada sebagian pegawai yang memiliki kinerja yang baik. Hal ini dapat dilihat dari hasil observasi awal, banyak pegawai yang hadir tepat waktu sesuai jam kerja yang telah ditetapkan. Selain itu, pegawai dapat bekerja sama dengan pegawai lain dan memiliki rasa saling membantu antarpegawai, terlebih saat dihadapkan pada tekanan pekerjaan yang padat. Hal ini mengindikasikan bahwa kinerja di kalangan PNS sudah tumbuh dan menjadi kesadaran kolektif. Tinggi rendahnya kinerja pegawai ini dapat dipengaruhi oleh beberapa faktor.

Salah satu aspek yang mempengaruhi kinerja pegawai yang diberikan adalah kepuasan kerja, artinya dengan tingkat kepuasan kerja yang tinggi biasanya pegawai akan memberikan kinerja yang baik, begitu juga sebaliknya ketika pegawai
Dispertanbunhut Kabupaten Boyolali tidak mengalami kepuasan maka kinerja yang diberikan tidak maksimal. Inilah peran pemimpin yang ada pada jajaran Dispertanbunhut Kabupaten Boyolali untuk menerapkan berbagai langkah yang mengarah pada peningkatan kepuasan kerja pegawainya.

Untuk dapat bekerja secara maksimal dengan kinerja yang tinggi, diperlukan pula motivasi individu dalam bekerja. Motivasi mengandung pengertian suatu proses menstimulasi manusia untuk melakukan kegiatan dalam upaya mencapai sasaran atau sasaran-sasaran yang diinginkan secara efektif dan efisien (Adisasmita, 2011). Motivasi dapat menjadi pendorong seseorang melaksanakan suatu kegiatan guna mendapatkan hasil yang terbaik. Oleh karena itulah tidak heran jika pegawai yang mempunyai motivasi kerja yang tinggi biasanya mempunyai kinerja yang tinggi pula.

Faktor lain yang mempengaruhi bagaimana dan mengapa orang-orang bekerja pada suatu organisasi dan bukan pada organisasi lainnya adalah kompensasi. Pemberian kompensasi sebagai balas jasa dan instansi atas kontribusi pegawai merupakan salah satu cara untuk memenuhi kebutuhan hidup dan meningkatkan taraf kesejahteraan mereka. Kompensasi penting bagi pegawai karena besarnya kompensasi mencerminkan ukuran nilai di antara pegawai itu sendiri, keluarga, dan masyarakat.

Penelitian ini bertujuan untuk menganalisis pengaruh motivasi dan kompensasi terhadap kepuasan kerja; pengaruh motivasi dan kompensasi terhadap kinerja pegawai; dan pengaruh kepuasan kerja terhadap kinerja pegawai di Dinas Pertanian, Perkebunan, dan Kehutanan Kabupaten Boyolali.

\section{Tinjauan Pustaka}

\section{Kinerja Pegawai}

Kinerja berasal dari kata job performance atau actual performance (prestasi kerja atau prestasi sesungguhnya yang dicapai oleh seseorang). Pengertian kinerja (prestasi 
kerja) adalah hasil kerja secara kualitas dan kuantitas yang dicapai oleh seorang pegawai dalam melaksanakan tugasnya sesuai dengan tanggung jawab yang diberikan kepadanya (Mangkunegara, 2007). Sedangkan Supriadi (2013) mengartikan kinerja sebagai kemampuan seseorang secara kualitas dan kuantitas dalam melaksanakan tugasnya sesuai dengan tanggung jawab yang diberikan kepadanya.

Pasolong (2007) mengatakan kinerja pegawai adalah hasil kerja perseorangan dalam suatu organisasi. Selanjutnya Withmore (dalam Sinambela et al., 2006) mengemukakan kinerja merupakan ekspresi potensi seseorang dalam memenuhi tanggung jawabnya dengan menetapkan standar tertentu.

a. Faktor yang Mempengaruhi Kinerja Pegawai

Faktor yang mempengaruhi pencapaian kinerja adalah faktor kemampuan (ability) dan faktor motivasi (motivation). Hal ini sesuai dengan pendapat Keith Davis dalam Mangkunegara (2007) yang merumuskan bahwa:

Human Performance $=$ Ability $\mathrm{x}$ Motivation

Motivation $\quad=$ Attitude $\mathrm{x}$ Situation

Ability

= Knowledge x Skill

1) Faktor kemampuan (ability). Secara Psikologis, kemampuan (ability) terdiri atas kemampuan potensi (IQ) dan kemampuan reality (knowledge+skill). Artinya, pimpinan dan karyawan yang memiliki IQ superior, very superior, gifted, dan genius dengan pendidikan yang memadai untuk jabatannya dan terampil dalam mengerjakan pekerjaan sehari-hari, maka akan lebih mudah mencapai kinerja maksimal.

2) Faktor motivasi (motivation). Motivasi diartikan suatu sikap (attitude) pimpinan dan karyawan terhadap situasi kerja (situation) di lingkungan organisasi. Mereka yang bersikap positif (pro) terhadap situasi kerjanya akan menunjukan motivasi kerja tinggi dan sebaliknya jika mereka bersikap negatif (kontra) terhadap situasi kerjanya akan menunjukkan motivasi kerja yang rendah. Situasi kerja yang dimaksud antara lain hubungan kerja, fasilitas kerja, iklim kerja, kebijakan pimpinan, pola kepemimpinan kerja, dan kondisi kerja.

b. Indikator Kinerja Pegawai. Hasibuan dalam Supriadi (2013) mengatakan bahwa kinerja pegawai dikatakan baik dapat dinilai dari beberapa hal:

1) Kesetiaan seorang pegawai, yaitu pegawai melakukan tugasnya secara sungguh-sungguh dan penuh tanggung jawab terhadap amanah yang diberikan organisasi.

2) Prestasikerja, yaituhasilyang dicapai pegawai dalam melaksanakan tugas yang dibebankan kepadanya. Pada umumnya prestasi kerja seorang pegawai dipengaruhi oleh kecakapan, keterampilan, pengalaman, dan kesanggupan pegawai dalam melaksanakan tugas dan fungsinya. Namun, prestasi kerja seorang pegawai tidak hanya tergantung dari kemampuan dan keahlian yang bersangkutan untuk menyelesaikan suatu pekerjaan.

3) Kedisiplinan, yaitu sejauh mana pegawai dapat mematuhi peraturan-peraturan yang ada dan melaksanakan instruksi yang diberikan kepadanya. Disiplin dapat diartikan melaksanakan apa yang telah disetujui bersama antara pimpinan dengan para pegawai, baik persetujuan tertulis, lisan, ataupun berupa peraturan-peraturan dan kebiasaan-kebiasaan.

4) Kreatifitas, yaitu kemampuan pegawai dalam mengembangkan 
ide-ide dan mengeluarkan potensi yang dimiliki dalam menyelesaikan pekerjaannya sehingga pegawai dapat bekerja dengan lebih berdaya guna dan berhasil guna.

4) Kerjasama, yaitu kemampuan pegawai untuk bekerja sama dengan pegawai lain dalam menyelesaikan suatu tugas yang ditentukan, sehingga hasil pekerjaannya akan semakin baik.

5) Kecakapan, yaitu tingkat pendidikan pegawai yang disesuaikan dengan pekerjaan yang menjadi tugasnya.

6) Tanggung jawab, yaitu kesanggupan seorang pegawai menyelesaikan pekerjaan yang diserahkan kepadanya dengan sebaik-baiknya dan tepat pada waktunya serta berani menerima risiko pekerjaan yang dilakukan.

\section{Kepuasan Kerja}

Brayfield et al. dalam Panggabean (2004) beranggapan bahwa kepuasan kerja dapat diduga dari sikap seseorang terhadap pekerjaannya. Kemudian Morse dalam Panggabean (2004) mengemukakan bahwa pada dasarnya, kepuasan kerja tergantung kepada apa yang diinginkan seseorang dari pekerjaannya dan apa yang mereka peroleh. Orang yang paling tidak merasa puas adalah mereka yang mempunyai keinginan paling banyak, tetapi mendapat yang paling sedikit. Sedangkan yang paling merasa puas adalah orang yang menginginkan banyak dan mendapatkannya.

Keith Davis dalam Mangkunegara (2007) mengemukakan bahwa "job satisfaction is the favorableness or unfavorableness with employees view their work" (kepuasan kerja adalah perasaan menyokong atau tidak menyokong yang dialami pegawai dalam bekerja). Wexley dan Yuki dalam Mangkunegara (2007) mendefinisikan kepuasan kerja "is the way an employee feels about his or her job" (cara pegawai merasakan dirinya atau pekerjaannya).
Berdasarkan pendapat Keith Davis, Wexley, dan Yuki tersebut, kepuasan kerja adalah suatu perasaan yang menyokong atau tidak menyokong diri pegawai yang berhubungan dengan pekerjaannya maupun dengan kondisi dirinya. Menurut Panggabean (2007) perasaan yang berhubungan dengan pekerjaan melibatkan aspek-aspek seperti upah atau gaji yang diterima, kesempatan pengembangan karier, hubungan dengan pegawai lainnya, penempatan kerja, jenis pekerjaan, struktur organisasi perusahaan, dan mutu pengawasan. Sedangkan perasaan yang berhubungan dengan dirinya, antara lain umur, kondisi kesehatan, kemampuan, dan pendidikan.

a. Indikator Kepuasan Kerja.

Kepuasan kerja berhubungan dengan variabel-variabel seperti turnover, tingkat absensi, umur, tingkat pekerjaan, dan ukuran organisasi perusahaan. Hal ini sesuai dengan pendapat Keith Davis dalam Mangkunegara (2007) yang mengemukakan bahwa "Job satisfaction is related to a number of major employee variables, such as turnover, absences, age, occupation, and size of the organization in which an employee works".

1) Turnover. Kepuasan kerja lebih tinggi dihubungkan dengan turnover pegawai yang rendah, sedangkan pegawai-pegawai yang kurang puas biasanya turnover-nya tinggi.

2) Tingkat kehadiran (absen) kerja. Pegawai-pegawai yang kurang puas cenderung tingkat ketidakhadirannya (absen) tinggi. Mereka sering tidak hadir kerja dengan alasan yang tidak logis dan subjektif.

3) Umur. Ada kecenderungan pegawai yang tua lebih merasa puas daripada pegawai yang berumur relatif muda. Hal ini diasumsikan bahwa pegawai yang lebih tua lebih berpengalaman menyesuaikan diridengan lingkungan pekerjaan. Sedangkan pegawai usia muda biasanya mempunyai harapan 
yang ideal tentang dunia kerjanya, sehingga apabila antara harapannya dengan realita kerja terdapat kesenjangan atau ketidakseimbangan dapat menyebabkan mereka menjadi tidak puas.

4) Tingkat pekerjaan.Pegawai-pegawai yang menduduki tingkat pekerjaan yang lebih tinggi cenderung lebih puas daripada pegawai yang menduduki tingkat pekerjaan yang lebih rendah. Pegawai-pegawai yang tingkat pekerjaannya lebih tinggi menunjukkan kemampuan kerja yang baik dan aktif dalam mengemukakan ide-ide serta kreatif dalam pekerjaan.

5) Ukuran organisasi perusahaan. Ukuran organisasi perusahaan dapat mempengaruhi kepuasan pegawai. Hal ini karena besar kecil suatu perusahaan berhubungan pula dengan koordinasi, komunikasi, dan partisipasi pegawai.

\section{Motivasi}

Motivasi berasal dari kata move yang artinya "bergerak". Motivasi adalah sesuatu yangmenggerakkanataumendorong seseorang atau kelompok orang untuk melakukan atau tidak melakukan sesuatu (Irianto, 2005). Motivasi adalah suatu proses menstimulasi manusia untuk melakukan kegiatan dalam upaya mencapai sasaran atau sasaran-sasaran yang diinginkan secara efektif dan efisien (Adisasmita, 2011). Sasaran yang dimaksud tentunya yang menyangkut kepentingan organisasi ataupun manajemen. Mengingat para pelaksana kegiatan adalah pribadi atau kelompok manusia, maka kegiatan manusia harus dilihat dari dua kepentingan, yakni kepentingan organisasi atau manajemen dan sasaran invidual sebagai sumber kepuasan pribadi.

Koontz (dalam Waluyo, 2007) menjelaskan motivasi menunjukkan dorongan dan usaha untuk memenuhi atau memuaskan sesuatu kebutuhan atau untuk mencapai suatu tujuan (motivation refers to the drive and effort to satisfy a want or will). Menurut Mangkunegara (2007) motif merupakan suatu dorongan kebutuhan dalam diri pegawai yang perlu dipenuhi agar pegawai tersebut dapat menyesuaikan diri terhadap lingkungannya, sedangkan motivasi adalah kondisi yang menggerakkan pegawai agar mampu mencapai tujuan dari motifnya.

a. Faktor yang Mempengaruhi Motivasi Kerja

Irianto (2005) mengelompokan faktor motivasi menjadi dua kelompok, yaitu:

1) Motivasi internal. Motivasi internal adalah motivasi dari dalam diri sendiri. Jenis motivasi ini dapat dibagi menjadi dua kelompok, yaitu motivasi internal positif dan motivasi internal negatif.

(a) Motivasi internal positif muncul karena keinginan untuk tumbuh berkembang dan mengekspresikan diri. Contoh: Ingin karier yang lebih baik, aktualisasi diri, dan sebagainya.

(b) Motivasi internal negatif muncul karena tekanan, ancaman ketakutan atau kekhawatiran. Misalnya: Takut tertinggal oleh kelompok atau lingkungan, takut kehilangan, takut menderita, dan sebagainya.

Motivasi internal sifatnya lebih permanen, mandiri, dan stabil. Karena dorongan berasal dari dalam, kondisi kejiwaan orang yang bersangkutanlah yang akan menentukan kuat tidaknya motivasi dan berlangsung lama atau tidaknya, tetapi secara umum dapat dikatakan bahwa sesuatu yang berasal dari dalam akan lebih permanen.

2) Motivasi eksternal. Motivasi eksternal adalah motivasi yang berasal dari luar diri. Motivasi ini dapat dibagi menjadi dua kelompok, 
yaitu motivasi eksternal positif dan motivasi eksternal negatif.
a) Motivasi eksternal positif biasanya berupa hadiah atau iming-iming yang membangkitkan niat orang untuk berbuat sesuatu, misalnya upah, komisi, insentif, promosi, dan sebagainya.

b) Motivasi eksternal negatif adalah sesuatu yang dipaksakan dari luar, agar orang menghindari sesuatu yang tidak diinginkan, misalnya sangsi, hukuman, peraturan-peraturan, tata tertib, termasuk ancaman PHK, dan sebagainya.

Motivasi eksternal bersifat sementara, tergantung, dan tidak stabil. Artinya, karena sifatnya sesuatu yang "dipasang" dari luar, kekuatannya bisa cepat pudar. Imingiming bisa cepat pudar, secepat bagaimana tanggapan orang terhadap iming-iming itu.

Herzberg (dalam Waluyo, 2007) mengelompokkan motivasi menjadi dua faktor. Faktor pertama, yaitu motivator mencakup gaji, upah, bonus, kebijakan perusahaan dan administrasi, kepastian jabatan, kondisi kerja, bimbingan supervisi, dan bimbingan para rekan kerja. Faktor kedua, yaitu higiene yang mencakup kemajuan, pengakuan dan status, pekerjaan, prestasi, kemungkinan pertumbuhan, dan tanggung jawab.

\section{b. Indikator Motivasi Kerja}

Ditinjau dari sisi perilaku dalam kehidupan berorganisasi menurut Suradinata (dalam Waluyo, 2007) ada sepuluh jenis kebutuhan yang sifatnya non materiel yang oleh anggota organisasi dipandang sebagai sesuatu hal yang turut mempengaruhi perilakunya dan menjadi faktor motivasional yang perlu mendapat perhatian pimpinan organisasi dalam mengendalikan pegawainya, yaitu:

1) Tempat kerja yang memadai;

2) Merasa diikutsertakan dalam bekerja;

3) Memberikan suatu cara disiplin kerja yang manusiawi;

4) Memberikan simpatik terhadap permasalahan pegawai;

5) Memberikan rasa aman dalam bekerja, baik dalam pelaksanaan kerja maupun masa yang akan datang;

6) Memberikan penghargaan bagi yang berprestasi dan memberikan sanksi bagi yang salah;

7) Menunjukkan kesetiaan bagi para pegawai;

8) Memberikan promosi maupun penyegaran jabatan;

9) Memberikan kesempatan untuk menambah ilmu pengetahuan kepada para pegawai;

10) Memberikan informasi tentang kebijakan organisasi dan memberikan pandangan terhadap kehidupan masa yang akan datang, agar hidup tenang sejahtera lahir batin.

Kesepuluh jenis kebutuhan tersebut melekat pada setiap pegawai atau para anggota suatu organisasi, di mana faktor motivasional dan kreavitas pegawai akan semakin berkembang dan pada gilirannya perilaku pegawai akan mendorong tercapainya tujuan, bahkan bukan hanya untuk memenuhi kepentingan pribadinya saja, melainkan juga tujuan-tujuan organisasi dapat tercapai.

\section{Kompensasi}

Kompensasi adalah semua jenis penghargaan yang berupa uang atau bukan uang yang diberikan kepada pegawai secara layak dan adil atasjasa mereka dalam mencapai tujuan perusahaan (Panggabean, 2004). Andrew E. Sikula (dalam Mangkunegara, 2007) mengemukakan bahwa: 
The process of wage or salary administration (or "compensation" as it is sometimes called) involves the weighting or balancing of accounts. A compensation is anything that constitutes or is regarded as an equivalent or recompense. In the employment world, financial rewards are the compensation resources provided to employees for the return of their services. The terms "remuneration", "wage", and "salary" also are used to describe this financial arrangement between employers and employees. A remuneration is a reward, payment, or reimbursement on occasion also may be nonfinancial in nature. Remunerations are usually in the form of comprehensive pay concepts than are the ideas of salary and wage that normally include a financial but not a nonfinancial dimension.

Berdasarkan pendapat Andrew tersebut dapat dikemukakan bahwa proses administrasi upah atau gaji (kadang-kadang disebut kompensasi) melibatkan pertimbangan atau keseimbangan perhitungan. Kompensasi merupakan sesuatu yang dipertimbangkan sebagai suatu yang sebanding. Dalam kepegawaian, hadiah yang bersifat uang merupakan kompensasi yang diberikan kepada pegawai sebagai penghargaan dari pelayanan mereka. Bentuk-bentuk pemberian upah, bentuk upah, dan gaji digunakan untuk mengatur pemberian keuangan antara majikan dan pegawainya.

Pada dasarnya kompensasi dapat dikelompokkan ke dalam dua kelompok, yaitu kompensasi finansial dan kompensasi bukan finansial. Selanjutnya, kompensasi finansial ada yang langsung dan ada yang tidak langsung. Sedangkan kompensasi nonfinansial dapat berupa pekerjaan dan lingkungan pekerjaan. Menurut Panggabean (2004) jenis-jenis kompensasi dapat dijelaskan sebagai berikut:

a. Gaji. Gaji adalah imbalan finansial yang dibayarkan kepada karyawan secara teratur, seperti tahunan, caturwulan, bulanan, atau mingguan.

b. Upah. Upah merupakan imbalan finansial langsung yang dibayarkan kepada para pekerja berdasarkan jam kerja, jumlah barang yang dihasilkan atau banyaknya pelayanan yang diberikan. Jadi tidak seperti gaji yang jumlahnya relatif tetap, besarnya upah dapat berubah-ubah. Pada dasarnya, gaji atau upah diberikan untuk menarik calon pegawai agar mau masuk menjadi karyawan.

c. Insentif. Insentif merupakan imbalan langsung yang dibayarkan kepada karyawan karena kinerjanya melebihi standar yang ditentukan. Dengan mengasumsikan bahwa uang dapat digunakan untuk mendorong karyawan bekerja lebih giat lagi, maka mereka yang produktif lebih menyukai gajinya dibayarkan berdasarkan hasil kerja.

d. Kompensasi tidak langsung (fringe benefit). Fringe benefit merupakan kompensasi tambahan yang diberikan berdasarkan kebijaksanaan perusahaan terhadap semua karyawan dalam usaha meningkatkan kesejahteraan para karyawan.

\section{Metode Penelitian}

Jenis penelitian yang digunakan dalam penelitian ini adalah kuantitatif. Penelitian ini mengambil tempat di Dinas Pertanian, Perkebunan, dan Kehutanan Kabupaten Boyolali. Populasi dalam penelitian ini adalah seluruh pegawai Dinas Pertanian, Perkebunan, dan Kehutanan Kabupaten Boyolali, yang berjumlah 60 orang. Adapun sampel yang digunakan dalam penelitian ini adalah seluruh pegawai sebanyak 60 orang dengan menggunakan teknik sampling jenuh.

Pengumpulan data dilakukan dengan menggunakan kuesioner, sedangkan pengukurannya menggunakan metode skala linkert. Penelitian ini menggunakan analisis yang dinamakan analisis jalur atau Path Analysis (PA) dengan bantuan software SPSS. Menurut Sarwono (2017) analisis jalur ialah 
suatu teknik untuk menganalisis hubungan sebab akibat yang terjadi pada regresi berganda jika variabel bebasnya mempengaruhi variabel tergantung tidak hanya secara langsung, tetapi juga secara tidak langsung.

\section{Hasil dan Pembahasan}

Analisis jalur digunakan untuk mengetahui pengaruh dari variabel bebas terhadap variabel terikat.

Tabel 1. Hasil Kesimpulan Regresi Jalur Total

\begin{tabular}{cccc}
\hline \multirow{2}{*}{ No } & Arah Hubungan & \multicolumn{2}{c}{ Regresi } \\
\cline { 3 - 4 } & Meta & Sig \\
\hline 1 & Motivasi $\rightarrow$ Kepuasan & 0,642 & 0,000 \\
2 & Kompensasi $\rightarrow$ Kepuasan & 0,339 & 0,004 \\
3 & Motivasi $\rightarrow$ Kinerja & 0,282 & 0,000 \\
4 & Kompensasi $\rightarrow$ Kinerja & 0,389 & 0,000 \\
5 & Kepuasan $\rightarrow$ Kinerja & 0,404 & 0,000 \\
\hline
\end{tabular}

Sumber: Data diolah, 2016

Tabel 2. Hasil Pengaruh Langsung, Pengaruh Tak Langsung, dan Pengaruh Total

\begin{tabular}{ccccc}
\hline No & Antar Variabel & $\begin{array}{c}\text { Pengaruh } \\
\text { Langsung }\end{array}$ & $\begin{array}{c}\text { Pengaruh Tak } \\
\text { Langsung }\end{array}$ & Total Pengaruh \\
\hline 1 & Motivasi $\rightarrow$ Kinerja & 0,282 & - & - \\
2 & Kompensasi $\rightarrow$ Kinerja & 0,389 & - & - \\
3 & Kepuasan $\rightarrow$ Kinerja & 0,404 & - & - \\
4 & Motivasi $\rightarrow$ Kepuasan $\rightarrow$ Kinerja & & $0,642 \times 0,404=0,259$ & $0,282+0,259=0,541$ \\
5 & Kompensasi $\rightarrow$ Kepuasan $\rightarrow$ Kinerja & & $0,339 \times 0,404=0,137$ & $0,389+0,137=0,526$ \\
\hline
\end{tabular}

Sumber: Data diolah, 2016

\section{a. Pengaruh Motivasi Terhadap} Kepuasan Kerja di Dinas Pertanian, Perkebunan, dan Kehutanan Kabupaten Boyolali

Hasil uji hipotesis menunjukkan nilai signifikansi yaitu $0,000<0,05$, dan $\mathrm{t}_{\text {hitung }}>\mathrm{t}_{\text {tabel }}$ $(6,398>1,671)$. Hal ini berarti motivasi berpengaruh positif dan signifikan terhadap kepuasan kerja Dinas Pertanian, Perkebunan, dan Kehutanan. Hasil penelitian tersebut senada dengan hasil penelitian dari Saleem et al. (2010) yang menunjukkan hubungan positif antara motivasi dan kepuasan kerja. Diperkuat dengan hasil penelitian dari Maharjan (2012) yang menyimpulkan bahwa terdapat hubungan positif antara motivasi kerja dan kepuasan kerja guru.

Karyawan merupakan konsumen internal yang harus pertama kali dipuaskan dengan pekerjaan mereka dalam rangka mendorong kepuasan. Karyawan yang puas umumnya menjadi karyawan yang lebih produktif.
Ogunnaike (2014) dalam penelitiannya menunjukkan motivasi kerja, baik itu motivasi intrinsik atau motivasi ekstrinsik merupakan hal yang penting dalam meningkatkan kepuasan kerja.

\section{b. Pengaruh Kompensasi Terhadap Kepuasan Kerja di Dinas Pertanian, Perkebunan, dan KehutananKabupaten Boyolali}

Hasil uji hipotesis menunjukkan nilai signifikansi yaitu $0,004<0,05$, dan $t_{\text {hitung }}>t_{\text {tabel }}$ $(3,044>1,671)$. Hal ini berarti kompensasi berpengaruh positif dan signifikan terhadap kepuasan kerja Dinas Pertanian, Perkebunan, dan Kehutanan. Didukung dengan hasil penelitian dari Adeoye dan Fields (2014) yang menyimpulkan bahwa terdapat hubungan antara kompensasi dan kepuasan kerja karyawan. Karyawan tidak puas dengan kompensasi yang mereka terima, mereka menganggap kompensasi tersebut 
tidak cukup dan tidak memadai. Hal ini mendukung pandangan yang diungkapkan dalam literatur bahwa jika pekerja tidak puas dengan kompensasi mereka, organisasi akan mengalami rendahnya tingkat kepuasan kerja, tingginya tingkat absensi, dan rotasi tenaga kerja.

Kompensasi memainkan peran penting dalam menentukan kepuasan kerja karyawan. Hal ini terjadi karena dua alasan, pertama, uang merupakan instrumen penting dalam memenuhi kebutuhan orang-orang; dan kedua, karyawan sering melihat gaji sebagai refleksi dari bentuk kepedulian manajemen terhadap mereka. Sejalan dengan temuan penelitian dari Gupta (2014) bahwa uang adalah motivator yang bagus, karyawan bekerja untuk uang, karyawan membutuhkan uang, gaji dan kompensasi yang bagus merupakan faktor kunci dalam memuaskan karyawan. Perusahaan dapat meningkatkan gaji dan kompensasi untuk memotivasi karyawan, gaji yang bagus dapat menjadi salah satu faktor kunci yang mempengaruhi kepuasan karyawan, juga dengan cara ini dapat meningkatkan kualitas pelayanan dan kinerja organisasi. Jika perusahaan menciptakan lingkungan yang kompetitif dan adil, seperti perlakuan yang adil, kompensasi yang adil, jam kerja yang adil, hal ini akan meningkatkan sikap kerja karyawan, keadilan juga dapat memotivasi karyawan untuk bekerja keras. Setelah pertimbangan inilah, dapat dilihat bahwa keadilan dapat meningkatkan kepuasan kerja karyawan. Karyawan yang puas dapat memberikan pelayanan yang baik bagi organisasi.

Pentingnya kompensasi dalam mempengaruhi kepuasan kerja juga senada dengan penelitian dari Muguongo (2015) di mana gaji pokok yang diterima mempengaruhi kepuasan kerja termasuk struktur gaji, konsistensi kebijakan, administrasi, dan pembayaran gaji tepat waktu. Selain itu, tunjangan seperti tunjangan rumah dan tunjangan kesusahan yang diterima guru mempengaruhi kepuasan kerja mereka. Bentuk kompensasi lainnya adalah reward.
Seperti penelitian Awan dan Asghar (2014) yang menunjukkan hubungan langsung antara sistem reward dan kepuasan kerja. Jika karyawan puas dengan sistem reward, karyawan memiliki kinerja yang baik. Tingkat motivasi mereka akan meningkat ketika mereka diberi reward atas kelayakan kinerja mereka.

\section{c. Pengaruh Motivasi Terhadap Kinerja Pegawai di Dinas Pertanian, Perkebunan, dan KehutananKabupaten Boyolali}

Hasil uji hipotesis menunjukkan nilai signifikansi yaitu $0,000<0,05$, dan $t_{\text {hitung }}>t_{\text {tabel }}(3,735>1,671)$. Hal ini berarti motivasi berpengaruh positif dan signifikan terhadap kinerja pegawai Dinas Pertanian, Perkebunan, dan Kehutanan. Senada dengan penelitian Seniwoliba dan Nchorbono (2013) yang menunjukkan motivasi berpengaruh signifikan terhadap kinerja pegawai. Semakin tinggi motivasi kerja akan mengakibatkan semakin tinggi pula kinerja pegawai. Seorang karyawan akan memiliki kinerja yang baik, jika memiliki keinginan, harapan, kebutuhan, tujuan, sasaran, dorongan, dan insentif yang didukung dengan kemampuan kerja yang baik. Sehingga dengan memotivasi serta meningkatkan kemampuan kerja karyawan maka dapat meningkatkan kinerja karyawan agar mampu mempertahankan perusahan dan tetap eksis pada era persaingan yang ketat.

Motivasi karyawan merupakan faktor penting bagi kemajuan perusahaan. Karyawan dengan motivasi tinggi akan menghasilkan kinerja terbaik dan produktif, sebaliknya karyawan dengan motivasi rendah akan rendah kinerja dan produktivitasnya (Soegoto, 2009). Motivasi karyawan merupakan suatu bentuk kesediaan untuk berusaha keras mencapai tujuan organisasi dengan memperhatikan usaha memuaskan beberapa kebutuhan, serta upaya untuk memperbaiki dan membentuk pengetahuan, sikap, dan perilaku karyawan sehingga karyawan tersebut secara sukarela berusaha bekerja secara kooperatif dengan para karyawan lainnya untuk meningkatkan 
kinerjanya (Amianti, 2012). Seorang pekerja yang memiliki motivasi akan berusaha untuk sebaik mungkin melaksanakan tugasnya agar menghasilkan kinerja yang tinggi dan hasil yang berkualitas. Motivasi yang tepat dan baik dapat meningkatkan dan menumbuhkan semangat kerja karyawan, sehingga menambah semangat kerja karyawan dalam bekerja, maka dengan demikian akan tercapai kinerja karyawan yang tinggi.

\section{d. Pengaruh Kompensasi Terhadap Kinerja Pegawai di Dinas Pertanian, Perkebunan, dan Kehutanan Kabupaten Boyolali}

Hasil uji hipotesis menunjukkan nilai signifikansi yaitu $0,000<, 05$, dan $t_{\text {hitung }}>t_{\text {tabel }}$ $(5,639>1,671)$. Hal ini berarti kompensasi berpengaruh positif dan signifikan terhadap kinerja pegawai Dinas Pertanian, Perkebunan, dan Kehutanan. Sejalan dengan penelitian dari Qureshi dan Sajjad (2015) yang menunjukkan hubungan positif antara kompensasi dan kinerja karyawan.

Pengaruh kompensasi terhadap kinerja pegawai juga diperkuat oleh Hameed et al. (2014) dalam penelitiannya, demikian pula dengan penelitian yang dilakukan oleh Jamil dan Raja (2011) di mana praktik kompensasi yang positif dan signifikan berhubungan dengan kinerja pegawai organisasi sektor publik. Tujuan dasar dari setiap organisasi publik adalah untuk mengompensasi karyawan dalam setiap cara yang memungkinkan. Bahkan, organisasi publik yang didirikan untuk menciptakan lapangan kerja. Kompensasi diperlukan untuk mendorong karyawan untuk bekerja lebih giat dengan harapan dapat meningkatkan imbalan yang diterimanya. Oleh karena itu kompensasi adalah entitas utama yang mempengaruhi kinerja karyawan.

\section{e. Pengaruh Kepuasan Kerja Terhadap Kinerja Pegawai di Dinas Pertanian, Perkebunan, dan Kehutanan Kabupaten Boyolali}

Hasil uji hipotesis menunjukkan nilai signifikansi yaitu $0,000<0,05$, dan $\mathrm{t}_{\text {hitung }}>\mathrm{t}_{\text {tabel }}$ $(5,318>1,671)$. Hal ini berarti kepuasan kerja berpengaruh positif dan signifikan terhadap kinerja pegawai Dinas Pertanian, Perkebunan, dan Kehutanan. Sejalan dengan penelitian dari Perera et al. (2014) bahwa kepuasan kerja berpengaruh positif terhadap kinerja karyawan.

Menurut penelitian Aftab dan Idrees (2012) terdapat hubungan positif antara kepuasan kerja dan kinerja karyawan. Kinerja tinggi dari setiap individu akan membantu organisasi untuk mencapai tujuan strategis sehingga dapat mempertahankan daya saing organisasi. Diperkuat dengan hasil penelitian dari Awan dan Asghar (2014) bahwa kinerja karyawan yang terbaik ketika mereka puas dengan berbagai aspek paket gaji mereka. Penelitian dari Afshar dan Doosti (2016) menunjukkan kepuasan kerja mempengaruhi kinerja secara positif. Kepuasan karyawan cenderung menjadikan kinerja yang lebih baik. Faktor yang paling berkontribusi terhadap ketidakpuasan kerja dan mempengaruhi kinerja karyawan adalah gaji yang rendah, tuntutan pekerjaan, adanya pekerjaan sampingan, rendahnya status pekerjaan, dan penghargaan sosial. 


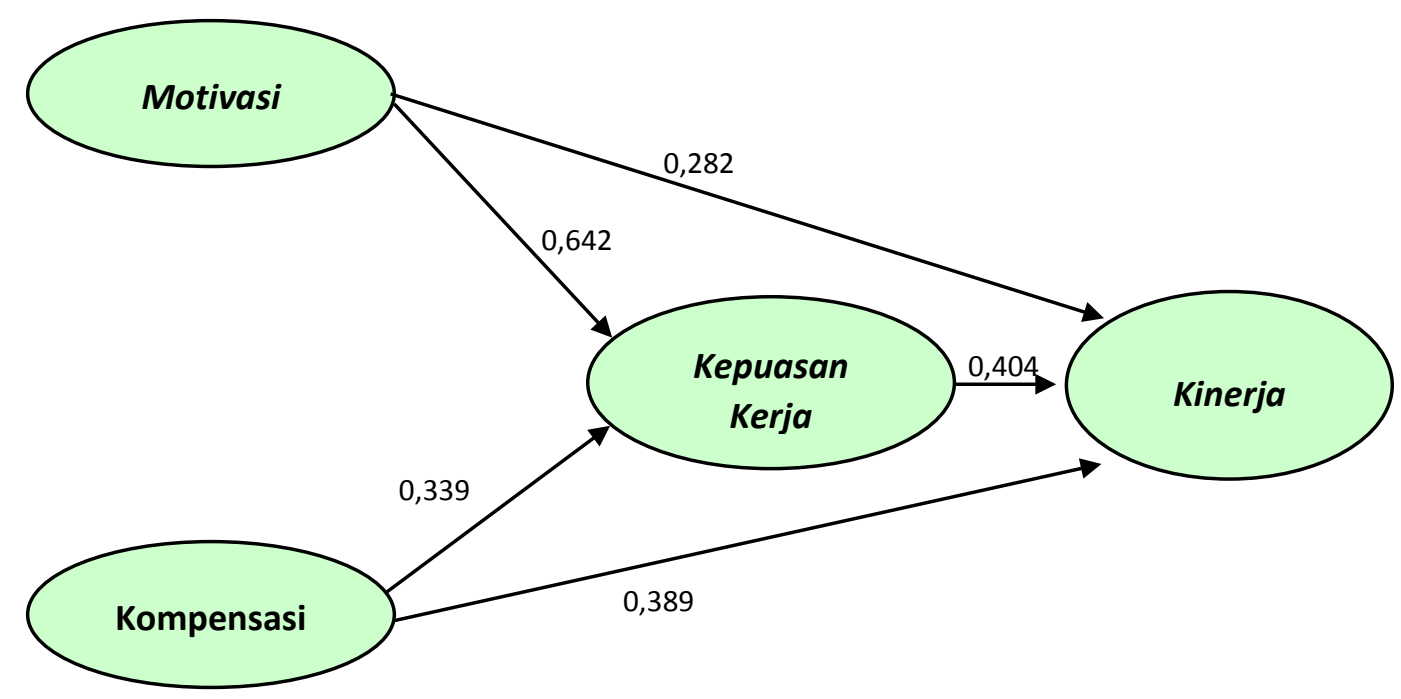

Gambar 1. Hasil Diagram Jalur

\section{Penutup}

Kesimpulan dari penelitian ini adalah variabel motivasi berpengaruh positif dan signifikan terhadap kkerja pegawai Dinas Pertanian, Perkebunan, dan Kehutanan Kabupaten Boyolali, dengan demikian hipotesis terbukti. Variabel kompensasi berpengaruh positif dan signifikan terhadap kepuasan kerja pegawai Dinas Pertanian, Perkebunan, dan Kehutanan Kabupaten Boyolali, dengan demikian hipotesis tidak terbukti. Variabel motivasi berpengaruh positif dan signifikan terhadap kinerja pegawai Dinas Pertanian, Perkebunan, dan Kehutanan Kabupaten Boyolali, dengan demikian hipotesis terbukti.

Variabel kompensasi berpengaruh positif dan signifikan terhadap kinerja pegawai Dinas Pertanian, Perkebunan, dan Kehutanan Kabupaten Boyolali, dengan demikian hipotesis terbukti. Variabel kepuasan kerja berpengaruh positif dan signifikan terhadap kinerja pegawai Dinas Pertanian, Perkebunan, dan Kehutanan Kabupaten Boyolali, dengan demikian hipotesis terbukti. Pada uji F menunjukkan bahwa persamaan 1, secara simultan variabel motivasi, kompensasi berpengaruh terhadap kepuasan kerja, dan persamaan 2 secara simultan variabel motivasi, kompensasi, kepuasan kerja berpengaruh terhadap kinerja pegawai di Dinas Pertanian, Perkebunan, dan Kehutanan Kabupaten Boyolali. Nilai $R$ square kedua persamaan sebesar 0,315, artinya variabel kinerja dijelaskan oleh motivasi, kompensasi, dan kepuasan kerja sebagai variabel intervening sebesar $31,5 \%$ dan sisanya sebesar $68,5 \%$ dijelaskan faktor lain di luar model penelitian. Hasil analisis jalur menunjukkan bahwa berdasarkan hasil analisis pengaruh langsung (direct effect) dan pengaruh tidak langsung (indirect effect) menunjukkan bahwa jalur langsung (direct effect) kepuasan berpengaruh paling kuat terhadap kinerja yang ditunjukkan dengan memiliki koefisien regresi pengaruh paling tinggi (dominan) sebesar 0,404. Hal tersebut lebih besar dibandingkan jalur yang lain. Maka dalam analisis jalur ini, kepuasan mestinya perlu mendapatkan perhatian dalam rangka meningkatkan kinerja pegawai yang cepat dan tepat.

Berdasarkan kesimpulan di atas, ada beberapa saran yang perlu disampaikan dalam penelitian ini: 1) hasil penelitian menunjukkan bahwa variabel kepuasan merupakan variabel yang paling dominan mempengaruhi kinerja di Dinas Pertanian, Perkebunan, dan Kehutanan. Untuk itu dalam meningkatkan kinerja, maka peningkatan kepuasan bagi pegawai perlu mendapat prioritas utama bagi semua pegawai. Pimpinan harus mampu memperhatikan secara khusus permasalahan dan kebutuhan pegawai, sehingga pegawai memperoleh kepuasan sesuai dengan yang diinginkan. 2) Peningkatan kinerja dapat dilakukan dengan cara pegawai selalu ikut serta dalam perencanaan dan pengembangan 
sumber daya manusia di Dinas Pertanian, Perkebunan, dan Kehutanan Kabupaten Boyolali. 3) Penelitian yang akan datang disarankan penambahan jumlah sampel lintas instansi yang sejenis dan variabel penelitian agar mampu menggeneralisasi hasil penelitian.

\section{Daftar Pustaka}

Adeoye, A.O. dan Fields, Z. 2014. Compensation Management and Employee Job Satisfaction: A Case of Nigeria. Journal Social Science, Vol. 41, No. 3, pp. 345-352.

Adisasmita, Rahardjo. 2011. Manajemen Pemerintah Daerah. Yogyakarta: Graha Ilmu.

Afshar, H. S. dan Doosti, M. 2016. Investigating the Impact of Job Satisfaction/ Dissatisfaction on Iranian English Teachers' Job Performance. Iranian Journal of Language Teaching Research, Vol. 4, No. 1, pp. 97-115.

Aftab, H. dan Idrees, W. 2012. A Study of Job Satisfaction and IT's Impact on the Performance in the Banking Industry of Pakistan. International Journal of Business and Social Science, Vol. 3, No. 19, pp. 174-180.

Amianti, I. dan Supriyanto. 2012. "Pengaruh Motivasi Kerja terhadap Kinerja Karyawan Bagian Marketing Bank Syariah (Studi kasus Pada karyawan PT. BPRS Pemerintah Kota Bekasi)". Maslahah, Vol. 1, No. 1, Maret 2012.

Awan, A.G. dan Asghar, I. 2014. IMPACT OF Employee Job Satisfaction on Their Performance. A Case Study of Banking Sector in Muzaffargarh District, Pakistan. Global Journal of Human Resource Management, Vol.2, No.4, pp.71-94.

Gupta, Manisha. 2014. Employees' Satisfaction Towards Monetary Compensation Practices. Global Journal of Finance and Management, Vol. 6, No. 8, pp. 757-764.

Hameed, A., Ramzan, M., Zubair, H.M.K., Ali, G. dan Arslan, M. 2014. Impact of Compensation on Employee Performance (Empirical Evidence from Banking Sector of Pakistan). International Journal of Business and Social Science, Vol. 5, No. 2, pp. 302-309.

Jamil, Bilal dan Naintara Sarfaraz Raja. 2011. "Impact of Compensation, Performance Evaluation and Promotion Practices on Government Employees Performance VS Private Employees Performance". Interdisciplinary Journal of Contemporary Research in Business, Vol. 3, No. 8, December 2011, 907-913.

Maharjan, Sarita. 2012. Association between Work Motivation and Job Satisfaction of College Teachers. Administrative and Management Review, Vol. 24, No. 2, pp. 45-55.

Muguongo, M.M., Muguna A.T., dan Muriithi D.K. 2015. Effects of Compensation on Job Satisfaction Among Secondary School Teachers in Maara Sub-County of Tharaka Nithi County, Kenya., Vol. 3, No. 6, pp. 47-59.

Perera, G.D.N., Khatibi, A., Navaratna, N., dan Chinna, K. 2014. Job Satisfaction and Job Performance Among Factory Employees in Apparel Sector. Asian Journal of Management Sciences \& Education, Vol. 3, No. 1, pp. 96-104.

Qureshi, M.O. dan Sajjad, S.R. 2015. An Empirical Analysis of the Impact of Compensation on Job Performance and Work-Family Conflict in the Kingdom of Saudi Arabia a Correlation Model. European Scientific Journal February 2015 edition, vol.11, No. 4, pp. 170-187.

Saleem, R., Mahmood, A. dan Mahmod, A. 2010. Effect of Work Motivation on Job Satisfaction 
in Mobile Telecommunication Service Organizations of Pakistan. International Journal of Business and Management, Vol. 5, No. 11, pp. 213-222.

Sarwono, Jonathan. 2007. Analisis Jalur untuk Riset Bisnis dengan SPPS. Yogyakarta: Andi.

Seniwoliba, A.J dan Nchorbono A.D. 2013. "Examining the Role of Motivation on Employee Performance in the Public Sector in Ghana". Merit Research Journal of Education and Review (ISSN: 2350-2282) Vol. 1(10) pp. 227-249, November, 2013.

Soegoto, Eddy S. 2009. Entrepreneurship Menjadi Pebisnis Ulung. Jakarta: PT. Elex Media Komputindo. 